\title{
ANALISIS RISIKO OPERASIONAL BERDASARKAN PENDEKATAN ENTERPRISE RISK MANAGEMENT (ERM) PADA PT. SWAKARYA INDAH BUSANA TANJUNGPINANG
}

\section{OPERATIONAL RISK ANALYSIS BASED ON ENTERPRISE RISK MANAGEMENT (ERM) APPROACH AT PT. SWAKARYA INDAH BUSANA TANJUNGPINANG}

\author{
Dwi Septi Haryani ${ }^{1)}$, Risnawati ${ }^{2)}$ \\ ${ }^{1}$ (Manajemen, STIE Pembangunan Tanjungpinang, Indonesia) \\ ${ }^{2}$ (Manajemen, STIE Pembangunan Tanjungpinang, Indonesia) \\ ${ }^{1}$ dwiseptih@stie-pembangunan.ac.id, ${ }^{2}$ risna.nina1988@gmail.com
}

\begin{abstract}
Abstrak
Di dalam mejalankan sebuah perusahaan pasti akan menghadapi risiko. Risiko yang muncul berasal dari lingkungan eksternal maupun lingkungan internal perusahaan yang membuat perusahaan mengalami kerugian. Tujuan dari penelitian ini adalah untuk menganalisis dan mengidentifikasi resiko operasional, untuk mengetahui dampak yang di timbulkan, dan untuk mengetahui tindakan yang perlu di lakukan sebagai antisipasi dan pencegahan atas resiko operasional yang dapat timbul di PT. Swakarya Indah Busana. Penelitian ini menggunakan pendekatan penelitian kualitatif deskriptif. Teknik pengumpulan data yang digunakan dalam penelitian ini adalah wawancara, observasi dan dokumentasi. Hasil penelitian menunjukkan bahwa risiko operasional yang terjadi pada PT. Swakarya Indah Busana meliputi dari risiko sumber daya manusia meliputi terjadinya pencurian bahan jadi oleh karyawan, kecelakaan kerja, strategi pengembangan karyawan kurang efektif, performa kinerja menurun, lalu risiko produktivitas meliputi pelaksanaan kerja tidak sesuai SOP, terjadi kerusakan mesin pada saat produksi, lalu risiko system meliputi terjadinya gangguan pada computer perusahaan yang menyebabkan data perusahaan hilang, kemudian risiko proses meliputi supplier terlambat mengirim barang, terjadinya kesalahan produksi sehingga menghasilkan produk yang cacat.
\end{abstract}

Kata Kunci: Enterprise Risk Management , Risiko, Operasional

\begin{abstract}
In running a company will inevitably face risks. Risk comes from the external environment internal environment of the company that made the company suffer losses. The purpose of this research is to analyse and identify operational risks, to know the impact of operational risk, and to know the actions that need to be done as the anticipation and prevention of operational risk can arise in a PT. Swakarya Indah Busana. This research uses descriptive qualitative approach method. Data collection techniques used in this research is the interview, observation and documentation. The results showed that operational risk is happening on PT. Swakarya Indah Busana covers from human resource risks include the occurrence of theft of material so by employees, work accident, employee development strategy for less effective performance, performance decreases, then the risk of covering the implementation of productivity of work is not appropriate the SOP, the crash engine at the time of production, then the risk of occurrence of disturbances on the system includes a computer company which caused the company data lost, then the risk process includes sending goods late supplier, the occurrence of an error resulting in the production of the product.
\end{abstract}

Keywords: Enterprise Risk Management, Risk, Operational 


\section{PENDAHULUAN}

Manajemen risiko juga selalu memberikan informasi yang mendasar mengenai suatu konsep manajemen risiko dalam aktivitas yang selalu dilakukan oleh perusahaan. Penerapan tersebut tidak hanya karena adanya ketentuan yang ada dalam mencapai sasaran bagi perusahaan. Bagian ini akan memberikan gambaran besar mengenai pentingnya suatu penerapan yang ada dalam proses manajemen risiko.

Risiko yang terjadi pada setiap perusahaan tentunya berbeda, perusahaan yang baik akan mampu untuk mengelola risiko yang terjadi,sehingga tingkat risiko yang terjadi bisa dikurangi atau dihilangkan (Mellisa \& Andono, 2013).

Dengan banyaknya risiko yang sering terjadi didalam suatu perusahaan atau perorangan, oleh sebab itu perlu adanya dilakukan pengelolaan dan pengendalian risiko supaya perusahaan bisa mempertahankan dan memperluas usahanya terutama yang mempunyai potensi kemampuan yang sangat erat seperti sekarang ini yang sudah berkembang. Adapun cara untuk mengolah dan mempersempit akibat dari risiko tersebut yaitu dengan menerapkan manajemen risiko agar dapat terkendali dan terkontrol.

Salah satu hal yang sangat penting dalam mengelola segala risiko yang dapat dikelola dan diminimalkan demi pencapaian tujuan perusahaan dengan cara menerapkan Enterprise Risk Management (ERM) yang juga penting dalam melakukan Enterprise Risk Management ini adalah karena masing-masing yang menggambarkan suatu pendekatan untuk mengidentifikasi, serta menganalisis, menanggapi dan pemantauan risiko dan peluang, dalam sebuah lingkungan dalam perusahaan maupun lingkungan luar perusahaan yang harus dihadapi oleh perusahaan.

Perusahaan PT Swakarya Indah Busana merupakan perusahaan bergerak dibidang garmen atau konveksi yang memproduksi pakaian jadi khususnya kemeja dan perusahaan ini merupakan satu-satunya perusahaan garmen yang ada di Kota Tanjungpinang, perusahaan ini sudah banyak memperoduksi kemeja. Perusahaan memiliki permintaan produk $60.000 \mathrm{kemeja/bulan.} \mathrm{Dengan} \mathrm{banyaknya} \mathrm{permintaan} \mathrm{dari} \mathrm{pelanggan,} \mathrm{perusahaan}$ harus melakukan sistem dengan produksi yang cepat dan tepat agar bisa memenuhi kepuasan dari pelanggan. Hal itu didukung untuk mencapainya tujuan dari perusahaan yakni untuk menjadi perusahaan yang berkualitas dan terpercaya di bidang kemeja 
dengan memberikan kualitas yang terbaik, ketepatan waktu pengiriman dan memberikan harga saing.

Sekarang ini, perusahaan belum melakukan identifikasi risiko dan manajemen risiko untuk mengelola dan mengatasi risiko-risiko yang mungkin akan terjadi di dalam perusahaan tersebut. Hal itu disadari oleh pihak perusahaan dikarenakan sudah terjadi beberapa peristiwa yang berhubungan dengan operasional perusahaan yang tidak diduga pada sebelumnya dan merugikan perusahaan. Dari hasil observasi awal dapat dilihat adanya risiko operasional perusahaan yang meliputi risiko sumber daya manusia, risiko produktivitas, risiko sistem, dan risiko proses, dari sini peneliti tertarik untuk meneliti di PT Swakarya Indah Busana dengan judul "Analisis Risiko Operasional Berdasarkan Pendekatan Enterprise Risk Management (ERM) Pada PT. Swakarya Indah Busana Kota Tanjungpinang”.

\section{Rumusan Masalah}

Berdasarkan latar belakang masalah diatas maka identifikasi masalahnya adalah bagaimana analisis risiko operasional berdasarkan pendekatan Enterprise Risk Management (ERM) pada PT. Swakarya Indah Busana kota Tanjungpinang?

\section{Tujuan Penelitian}

Berdasarkan masalah yang telah dirumuskan diatas tujuan dari penelitian ini adalah untuk mengetahui analisis risiko opersional berdasarkan pendekatan Enterprise Risk Management (ERM) pada PT. Swakarya Indah Busana Kota Tanjungpinang.

\section{Tinjauan Pustaka}

\section{Risiko}

Menurut Miller (1992), istilah "risiko" secara konvensional telah digunakan untuk merujuk kepada segala macam ketidakpastian yang terkait dengan hasil dari sebuah organisasi (Luppino, Hosseini, \& Rameezdeen, 2014). Risiko juga merupakan penyimpangan dari sesuatu yang diharapkan. Karena faktor ketidak pastian inilah yang akhirnya menyebabkan timbulnya risiko pada suatu kegiatan (Mulyawan, 2015).

Risiko Operasional menurut Telkom (Wiryono \& Suharto, 2008), adalah risikorisiko yang terdapat dalam kegiatan operasional sehari-hari perusahaan yang baik secara langsung maupun tidak langsung muncul dari ketidakcukupan atau kegagalan proses 
internal, orang dan sistem atau dari kejadian luar kendali perusahaan, termasuk bencana alam.

\section{Manajemen Risiko}

Manajemen risiko juga merupakan cara dalam mengorganisasikan suatu risiko yang akan dihadapi, baik sudah diketahui maupun yang belum diketahui atau yang tak terpikirkan yaitu dengan memindahkan risiko kepada pihak lain, menghindari risiko, mengurangi efek negative risiko, dan menampung sebagian atau semua konsekuensi risiko tertentu (Darmawi, 2016).

\section{Proses Manajemen Risiko}

Manajemen risiko pada dasarnya dilakukan melalui proses (Hanafi, 2014):

1. Identifikasi Risiko

2. Evaluasi dan Pengukuran Risiko

3. Pengelolaan Risiko

Menurut (Fahmi, 2010), risiko dapat dikelola oleh 4 cara ini:

1. Meminimalkan risiko, dalam cara yang tidak memperbesar keputusan yang mengandung risiko tinggi tetapi membatasi sehingga risiko tersebut tidak tumbuh di luar kendali perusahaan.

2. Mengalihkan risiko, dengan risiko bahwa risiko ditransfer kepada pihak lain.

3. Mengendalikan risiko, dengan melakukan kebijakan antisipasi risiko sebelum terjadi.

4. Mendanai risiko, berkaitan dengan penyediaan sejumlah dana sebagai cadangan untuk mengantisipasi terjadinya risiko.

\section{Enterprise Risk Management (ERM)}

Enterprise Risk Management (ERM) yaitu organisasi yang memerlukan sistem dan prosedur administrasi yang efesien, serta efektif (Darmawi, 2016). Menurut Committee of Sponsoring Organizations of the Treadway Commission (COSO) kerangka mendefinisikan Enterprise Risk Management (ERM) sebagai proses, dipengaruhi oleh Dewan Direksi, manajemen dan personel lain, diterapkan dalam strategi pengaturan dan di perusahaan, dirancang untuk mengidentifikasi potensi peristiwa yang mungkin mempengaruhi entitas, dan mengelola risiko dalam resiko yang, untuk memberikan jaminan yang wajar mengenai pencapaian tujuan entitas (Mustapha \& Adnan, 2015). 


\section{Komponen-Komponen ERM}

Menurut Moeller (2009), ada beberapa komponen ERM berikut (Sirait \& Susanty, 2016):

1. Lingkungan internal (internal environment), sangat menentukan warna dari sebuah organisasi dan member jasa bagi cara pandang terhadap risiko dari setiap orang dalam organisasi tersebut.

2. Penentuan tujuan (objectif sefting), manajemen harus menetapkan tujuan-tujuan dari organisasi agar dapat mengidentifikasi, mengakses, dan mengelola risiko.

3. Identifikasi kejadian (event identification), dimana komponen ini mengidentifikasi kejadian-kejadian pontensial baik yang terjadi dilingkungan internal maupun ekternal organisasi yang mempengaruhi strategi atau pencapaian tujuan dari organisasi.

4. Penilaian risiko (risk assessment), dimana kommpopnen ini menilai sejauh mana dampak dari kejadian dapat mengganggu pencapaian dari tujuan.

5. Respon resiko (risk respon), sebuah organisasi harus dapat menentukan sikap atas hasil penilaian risiko.

6. Kegiatan pengendalian (control acivities), kebijakan dan prodesur ditetapkan dan diimplementasikan untuki membantu memastikan respon resiko berjalan dengan efektif

7. Informasi dan komunikasi (information and communication), informasi yang relevan diidentifikasi, ditangkap, dan dikomunikasikan, dalam bentuk atau waktu yang memungkinkan setiap orang menjalankan tanggungjawabnya

8. Pengawasan (monitoring), keseluruhan proses ERM dimonitor dan modiufikasi dilakukan apabila perlu.

\section{METODOLOGI}

\section{Pendekatan}

Penelitian ini merupakan penelitian kualitatif. Dengan menggunakan desain penelitian deskriptif dengan pendekatan kualitatif bertujuan untuk menggali mengenai fakta operasional berdasarkan pendekatan Enterprise Risk Management (ERM). Sumber data yang digunakan adalah data primer yaitu melalui wawancara dan data sekunder yang didapat dari buku referensi, jurnal, dan internet. Teknik pengumpulan data yang digunakan dalam penelitian ini adalah wawancara, observasi dan dokumentasi. 


\section{Objek Penelitian}

Dalam penelitian ini, objek penelitiannya adalah PT. Swakarya Indah Busana yang beralamat di Jln. D.I Panjaitan Km. 7 Kota Tanjungpinang. Ruang lingkup penelitian ini hanya pada variabel-variabel yang berkaitan dengan risiko operasional. Yang menjadi informan dalam penelitian ini adalah satu orang manajer produksi yang bernama Amintas dan satu orang karyawan Desi Yanputri. Teknik pengambilan sample menggunakan purposive sampling dimana pertimbangannya adalah orang yang dijadikan sebagai informan yang memahami betul kondisi operasional pada PT. Swakarya Indah Busana.

\section{PEMBAHASAN}

\section{Identifikasi Risiko}

Identifikasi risiko yang dapat terjadi di PT swakarya Indah Busana didasarkan dari proses bisnis yang berjalan di perusahaan garmen. Pada penelitian ini risiko-risiko difokuskan pada risiko operasional dikarenakan beberapa permasalahan yang telah terjadi berasal dari operasional perusahaan, dimana risiko yang terjadi di perusahaan terdiri dari risiko sumber daya manusia, risiko produktivitas, risiko sistem, dan risiko proses. Identifikasi risiko pertama dilakukan di perusahaan garmen dengan melihat secara langsung dilapangan, melakukan wawancara dengan bagian manajer produksi. Kemudian membuat daftar indikator risiko-risiko yang mungkin akan terjadi dari tiga jurnal yang diambil, kemudian melakukan pemilihan indikator dengan cara mengurangi atau menambahi indikator risiko yang mungkin akan terjadi di dalam perusahaan tersebut.

Tabel.1 Identifikasi Risiko di PT Swakarya Indah Busana

\begin{tabular}{|l|l|l|}
\hline Jenis Risiko & Kode & Peristiwa \\
\hline Risiko & A1 & terjadinya pencurian bahan jadi oleh karyawan \\
\cline { 2 - 3 } $\begin{array}{l}\text { Suya } \\
\text { Manusia }\end{array}$ & A2 & Terjadinya Kecelakaan kerja pada saat kerja \\
\cline { 2 - 3 } & A3 & Strategi pengembangan karyawan kurang efektif \\
\cline { 2 - 3 } $\begin{array}{l}\text { Risiko } \\
\text { Produktivitas }\end{array}$ & B1 & Performa pekerja menurun \\
\cline { 2 - 3 } $\begin{array}{l}\text { Risiko } \\
\text { Sistem }\end{array}$ & B2 & terjadi kerusakan mesin pada saat produksi \\
\hline
\end{tabular}




\begin{tabular}{|l|l|l|}
\hline Risiko & D1 & Supplier terlambat mengirim barang \\
\cline { 2 - 3 } Proses & D2 & $\begin{array}{l}\text { Terjadinya kesalahan produksi sehingga memhasilkan } \\
\text { produk yang cacat }\end{array}$ \\
\hline
\end{tabular}

Sumber: Data Primer yang Diolah

\section{Penilaian Risiko}

Setelah melakukan mengidentifikasi risiko-risiko yang mungkin terjadi yang ada diperusahaan, kemudian melakukan penilaian risiko. Diketahui bahwa terdapat 9 risiko yang dapat terjadi pada perusahaan tersebut. Penilaian risiko dilakukan berdasarkan probabilitas dan dampak yang terjadi.

Tabel 2 Penilaian Risiko Operasional di PT Swakarya Indah Busana

\begin{tabular}{|c|c|c|c|c|c|}
\hline $\begin{array}{l}\text { Jenis } \\
\text { Risiko }\end{array}$ & No & Peristiwa & Probabilitas & Dampak & $\begin{array}{l}\text { Nilai } \\
\text { Risiko }\end{array}$ \\
\hline \multirow{4}{*}{$\begin{array}{l}\text { Risiko } \\
\text { Sumbe } \\
\text { r Daya } \\
\text { Manus } \\
\text { ia }\end{array}$} & A1 & $\begin{array}{l}\text { Terjadinya pencurian } \\
\text { bahan jadi oleh } \\
\text { karyawan }\end{array}$ & 5 & 4 & High \\
\hline & $\mathrm{A} 2$ & $\begin{array}{l}\text { Terjadinya kecelakaan } \\
\text { kerja pada saat kerja }\end{array}$ & 4 & 3 & High \\
\hline & A3 & $\begin{array}{l}\text { Strategi pengembangan } \\
\text { karyawan kurang } \\
\text { efektif }\end{array}$ & 3 & 3 & Medium \\
\hline & A4 & $\begin{array}{l}\text { Performa pekerja } \\
\text { menurun }\end{array}$ & 2 & 4 & Medium \\
\hline \multirow{2}{*}{$\begin{array}{l}\text { Risiko } \\
\text { Produ } \\
\text { ktivita } \\
\quad \text { s }\end{array}$} & B1 & $\begin{array}{l}\text { Pelaksanaan kerja tidak } \\
\text { sesuai SOP }\end{array}$ & 2 & 4 & Medium \\
\hline & B2 & $\begin{array}{l}\text { Terjadi kerusakan } \\
\text { mesin pada saat } \\
\text { produksi }\end{array}$ & 2 & 3 & Medium \\
\hline $\begin{array}{l}\text { Risiko } \\
\text { Sistem }\end{array}$ & $\mathrm{C} 1$ & $\begin{array}{l}\text { Terjadinya gangguan } \\
\text { pada komputer } \\
\text { perusahaan } \\
\text { Yang menyebabkan } \\
\text { data perusahaan hilang }\end{array}$ & 2 & 3 & Medium \\
\hline \multirow[t]{2}{*}{$\begin{array}{l}\text { Risiko } \\
\text { Proses }\end{array}$} & D1 & $\begin{array}{l}\text { Supplier terlambat } \\
\text { mengirim barang }\end{array}$ & 2 & 2 & Low \\
\hline & D2 & $\begin{array}{l}\text { Terjadinya kesalahan } \\
\text { produksi sehingga } \\
\text { memhasilkan produk } \\
\text { yang cacat }\end{array}$ & 3 & 4 & High \\
\hline
\end{tabular}

Sumber: Data Primer yang Diolah 
Selanjutnya dibuat pemetaan risiko dalam Likelihood-impact Matrix, yang disajikan dalam Gambar 1.

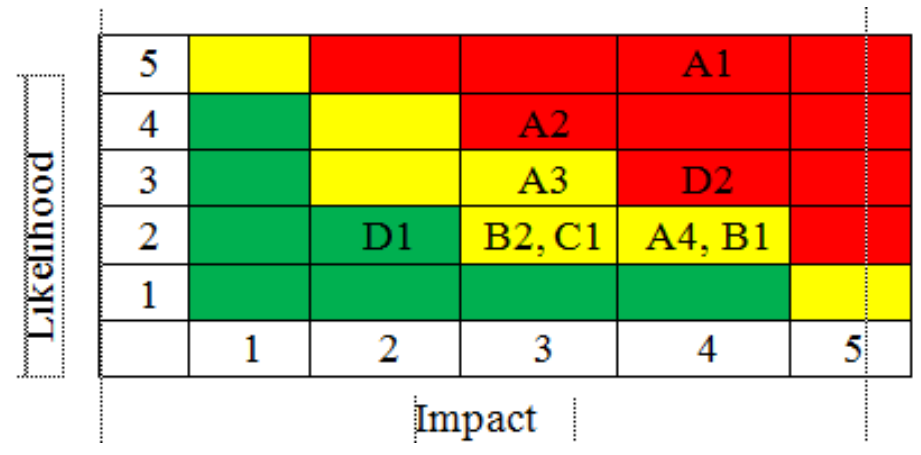

Gambar 1 Likelihood-Impact Matrix

Sumber: Data Primer Yang Diolah

Keterangan: Hijau: Low Risk, Kuning: Medium Risk, Merah: High Risk

Berdasarkan gambar peta risiko, maka dari sini dapat dikelompok sebagai berikut:

1. Low Risk

Risiko yang termasuk di dalam kelompok low risk adalah supplier terlambat mengirim barang (D1). Adapun cara metode pengelolaan risiko pada kelompok ini dengan menerima risiko karena dampak yang dihasilkan sangat tendah.

2. Medium Risk

Risiko yang termasuk di dalam kategori medium risk ialah strategi pengembangan karyawan kurang efektif (A3), performa pekerja menurun (A4), pelaksanaan kerja tidak sesuai SOP (B1), terjadi kerusakan mesin pada saat produksi (B2), terjadinya gangguan pada komputer perusahaan yang menyebabkan data perusahaan hilang (C1).

\section{High Risk}

Risiko kelompok ini yaitu terjadinya pencurian bahan jadi oleh karyawan (A1), terjadi kecelakaan kerja pada saat bekerja (A2), terjadi kesalahan produksi sehingga menghasilkan produk yang cacat (D2).

\section{Pengelolaan Risiko}

Setelah melakukan pengelompokan risiko maka melakukan pengelolaan risika dengan cara penghindaran risiko, risiko ditahan, diversifikasi risiko, transfer risiko, pengendalian risiko dan pendanaan risiko dan memberikan agrumen, sebagai berikut: 
Tabel 3 Pengelolaan Risiko

\begin{tabular}{cll}
\hline No & Pengelolaan risiko & Argumen \\
\hline A1 & Pengendalian risiko & $\begin{array}{l}\text { Dengan mengendalikan risiko maka pencurian } \\
\text { bahan jadi tidak akan terjadi lagi }\end{array}$ \\
\hline A2 & Pengendalian risiko & $\begin{array}{l}\text { Agar tidak terjadi lagi kecelakaan yang menimpa } \\
\text { karyawan }\end{array}$ \\
\hline A3 & Pengendalian risiko & $\begin{array}{l}\text { Agar pengembangan karyawan bisa ditingkatkan } \\
\text { lagi }\end{array}$ \\
\hline A4 & Pengendalian risiko & Agar performa karyawan lebih efektif dan efisien \\
\hline B1 & Pengendalian risiko & $\begin{array}{l}\text { Harus dikendalikan agar karyawan bekerja sesuai } \\
\text { SOP }\end{array}$ \\
\hline B2 & Pendanaan risiko & $\begin{array}{l}\text { Agar tidak ada kerugian yang cukup besar pada } \\
\text { perusahaan }\end{array}$ \\
\hline C1 & Transfer risiko & Dengan mentransfer maka data bisa di back up \\
\hline D1 & Terima risiko & Terima karena jarang terjadi pada risiko ini \\
\hline D2 & Pengendalian risiko & $\begin{array}{l}\text { Harus di kendalikan agar tidak ada lagi produk } \\
\text { yang cacat }\end{array}$ \\
\hline Sumber & Data Sekunder Yang & Diolah
\end{tabular}

Sumber: Data Sekunder Yang Diolah

\section{Rekomendasi Penanganan Risiko}

Setelah melakukan pengelolaan risiko maka disini ada rekomendasi penanganan terhadap masing-masing risiko di PT Swakarya Indah Busana sebagai berikut:

\section{Tabel 4 Rekomendasi Penanganan Risiko}

\begin{tabular}{|c|c|c|}
\hline No & Risiko & Tindakan penanganan \\
\hline A1 & $\begin{array}{l}\text { terjadinya pencurian bahan jadi oleh } \\
\text { karyawan }\end{array}$ & $\begin{array}{l}\text { Memasang cctv di area yang } \\
\text { penting, menjaga keamanan yang } \\
\text { lebih baik lagi }\end{array}$ \\
\hline $\mathrm{A} 2$ & $\begin{array}{l}\text { Terjadinya Kecelakaan kerja pada saat } \\
\text { kerja }\end{array}$ & $\begin{array}{llr}\text { Para karyawan harus lebih } \\
\begin{array}{l}\text { berhati-hati lagi } \\
\text { pekerjaannya }\end{array} & & \\
\end{array}$ \\
\hline A3 & $\begin{array}{l}\text { Strategi pengembangan karyawan } \\
\text { kurang efektif }\end{array}$ & $\begin{array}{l}\text { Dengan cara diadakannya } \\
\text { pelatihan secara berkala }\end{array}$ \\
\hline A4 & Performa pekerja menurun & $\begin{array}{l}\text { Bisa dengan memberikan berupa } \\
\text { hadiah seperti bonus agar } \\
\text { performa karyawan meningkat }\end{array}$ \\
\hline B1 & Pelaksanaan kerja tidak sesuai SOP & $\begin{array}{l}\text { Memberikan sanksi berat bagi } \\
\text { yang bekerja tidak sesuai SOP }\end{array}$ \\
\hline $\mathrm{B} 2$ & $\begin{array}{l}\text { terjadi kerusakan mesin pada saat } \\
\text { produksi }\end{array}$ & $\begin{array}{l}\text { Membuat data penyusutan mesin } \\
\text { dan selalu dicek secara berkala }\end{array}$ \\
\hline $\mathrm{C} 1$ & $\begin{array}{l}\text { Terjadinya gangguan pada komputer } \\
\text { perusahaan } \\
\text { yang menyebabkan data perusahaan } \\
\text { hilang }\end{array}$ & $\begin{array}{l}\text { Memasang anti virus } \\
\text { meningkatkan keamanan } \\
\text { komputer }\end{array}$ \\
\hline
\end{tabular}




\begin{tabular}{lll}
\hline D1 & Supplier terlambat mengirim barang & $\begin{array}{l}\text { Melakukan perencanaan dan } \\
\text { koordinasi dengan baik. }\end{array}$ \\
\hline D2 & $\begin{array}{l}\text { Terjadinya kesalahan produksi } \\
\text { sehingga memhasilkan produk yang } \\
\text { cacat }\end{array}$ & $\begin{array}{l}\text { Diberi sanksi agar karyawan } \\
\text { bekerja lebih teliti lagi }\end{array}$ \\
\hline
\end{tabular}

\section{KESIMPULAN}

Dari hasil penelitian di PT Swakarya Indah Busana, dimulai dari langkah mengidentifikasi risiko terdapat 9 risiko yang mungkin terjadi di perusahaan tersebut. Resiko operasional perusahaan meliputi dari risiko sumber daya manusia meliputi terjadinya pencurian bahan jadi oleh karyawan, kecelakaan kerja, strategi pengembangan karyawan kurang efektif, performa kinerja menurun.

Lalu risiko produktivitas meliputi pelaksanaan kerja tidak sesuai SOP, terjadi kerusakan mesin pada saat produksi, lalu risiko system meliputi terjadinya gangguan pada komputer perusahaan yang menyebabkan data perusahaan hilang, kemudian risiko proses meliputi supplier terlambat mengirim barang, terjadinya kesalahan produksi sehingga menghasilkan produk yang cacat.

Setelah itu melakukan penilaian risiko dengan cara mengetahui probabilitas dan dampak dari risiko, dari sini diketahui terdapat satu low risk, lima medium risk dan tiga high risk dengan menggunakan peta risiko. Terdapat beberapa cara pengelolaan risiko yakni menghindari risiko, risiko ditahan, diversifikasi risiko, transfer risiko, pengendalian risiko dan pendanaan risiko. Setelah pengelolaan ada rekomendasi penanganan yang dilakukan dengan cara memberikan agrumen-agrumen yang bisa memberikan penanganan risiko-risiko yang mungkin terjadi agar bisa lebih efektif dan efisien.

\section{REFERENSI}

Darmawi, H. (2016). Manajemen Risiko (2nd ed.). Jakarta: PT. Bumi Aksara.

Fahmi, I. (2010). Manajemen Risiko. Bandung: Alfabeta.

Hanafi, M. M. (2014). Manajemen Risiko (2nd ed.). Yogyakarta: UPP STIM YKPN.

Luppino, R., Hosseini, M. R., \& Rameezdeen, R. (2014). Risk management in research and development (R\&D) projects: The case of South Australia. Asian Academy of Management Journal, 19(2), 67-85. 
Mellisa, \& Andono, F. A. (2013). PENERAPAN ENTERPRISE RISK MANAGEMENT DALAM RANGKA MENINGKATKAN EFEKTIFITAS KEGIATAN OPERASIONAL "CV. ANUGERAH BERKAT CALINDOJAYA." Calyptra: Jurnal Ilmiah Mahasiswa Universitas Surabaya, 2(1). https://doi.org/10.1017/CBO9780511778711.004

Mulyawan, S. (2015). Manajemen Risiko. Bandung: CV.Pustaka Setia.

Mustapha, M., \& Adnan, A. (2015). A Case Study of Enterprise Risk Management Implementation in Malaysian Construction Companies. International Journal of Economics and Financial Issues, 5(2), 70-76.

Sirait, N. M., \& Susanty, A. (2016). ANALISIS RISIKO OPERASIONAL BERDASARKAN PENDEKATAN ENTERPRISE RISK MANAGEMENT ( ERM ) PADA PERUSAHAAN. Industrial Engineering Online Journal, 5(4).

Wiryono, S. K., \& Suharto. (2008). Analisis Risiko Operasional di PT TELKOM dengan pendekatan Metode ERM. Jurnal Manajemen Teknologi, 7(1). 